\title{
Karakteristik termogravimetri dan kinetika dekomposisi EPDM dengan bahan pengisi carbon black
}

\section{Thermogravimetric characteristics and decomposition kinetics of EPDM filled with carbon black}

\author{
Hesty Eka Mayasari*, Arum Yuniari \\ Balai Besar Kulit, Karet, dan Plastik, Jl. Sokonandi No. 9 Yogyakarta, 55166, Indonesia \\ *Penulis korespondensi. Telp.: +6274 512929,563939, Fax.: +6274 563655 \\ E-mail: hesty.ekamayasari@yahoo.com
}

Diterima: 5 September 2016 Direvisi: 28 Oktober 2016 Disetujui: 29 Oktober 2016

\begin{abstract}
The thermal characteristics of a material are important to learn in order to know the thermal stability of the materials. Ethylene propylene diene monomer (EPDM) is a synthetic rubber that is widely used in industry due to its resistance to aging, ozone, and chemicals. The kinetic parameters and thermal decomposition of vulcanized EPDM were studied using thermogravimetric method with various vulcanization systems (efficient, semi-efficient, and conventional vulcanization system) and various carbon black (CB) as filler (50,60, and 70 phr). Decomposition consist of two stages; the oxidation of EPDM and volatile matter loss then decomposition of EPDM. Kinetic parameters of the thermal decomposition were approximated by the Coats Redfern equation. Activation energy and decomposed mass increases with decreasing content of CB. Vulcanized EPDM with CB as filler has fairly good resistance against thermal decomposition. The decomposition process can be viewed in detail in this paper.
\end{abstract}

Keywords: EPDM, thermal decomposition, kinetic, thermogravimetric, carbon black.

\begin{abstract}
ABSTRAK
Karakteristik termal suatu material penting untuk dipelajari untuk mengetahui stabilitas termal bahan tersebut. Etilen propilen diena monomer (EPDM) adalah salah satu karet sintetis yang banyak digunakan dalam industri karena ketahanan terhadap aging, ozon, dan kimia yang baik. Pada studi ini akan dipelajari parameter kinetika dan sifat dekomposisi termal vulkanisat EPDM dengan metode termogravimetri dari berbagai variasi sistem vulkanisasi (efisien, semi-efisien, dan konvensional) dan variasi carbon black (CB) (50,60, dan 70 phr) sebagai bahan pengisi. Dekomposisi terjadi dalam dua tahap; oksidasi EPDM dan hilangnya bahan mudah menguap kemudian dekomposisi EPDM. Parameter kinetika dekomposisi termal didekati dengan persamaan Coats Redfern. Energi aktivasi dan massa yang terdekomposisi meningkat dengan berkurangnya kandungan CB. Vulkanisat EPDM dengan bahan pengisi CB memiliki ketahanan cukup baik terhadap dekomposisi termal. Proses dekomposisi dapat dilihat secara detail pada paper ini.
\end{abstract}

Kata kunci: EPDM, dekomposisi termal, kinetika, termogravimetri, carbon black.

\section{PENDAHULUAN}

Material polimer yang telah mengalami proses pengolahan, penggunaan, dan penyimpanan akan mengalami degradasi karena pengaruh suhu dan waktu. Degradasi ini dapat disebabkan oleh bahan kimia seperti pemutusan ikatan dan oksidasi atau perubahan fisik yang menghasilkan bahan dengan sifat yang berbeda dalam struktur polimernya. Pada umumnya sifat fisika dan sifat mekanis akan menurun. Tingkat perubahan sifat termal oleh pengaruh suhu disebut sebagai ukuran stabilitas termal suatu bahan (Alneamah \& Almaamori, 2015).

EPDM adalah karet nonpolar dan memiliki sedikit ikatan tidak jenuh sehingga memiliki sifat ketahanan yang baik terhadap bahan kimia, cuaca, dan pengusangan. Rumus struktur EPDM dapat dilihat pada Gambar 1. EPDM adalah salah 


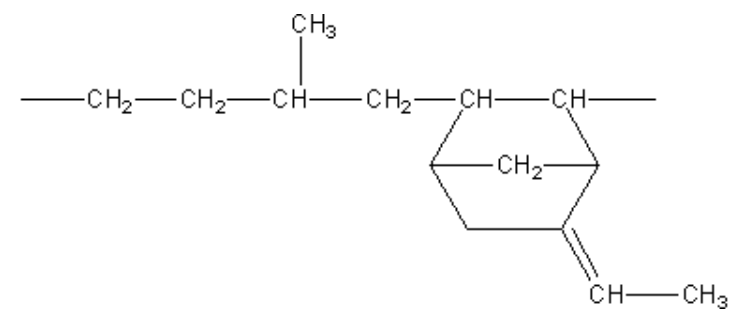

Gambar 1. Rumus struktur EPDM.

satu karet sintetis yang banyak digunakan dalam bidang industri dan otomotif. EPDM mempunyai waktu pematangan yang lambat dan waktu induksi yang lama (Choi et al., 2006). Dalam proses pembuatan vulkanisat, dibutuhkan beberapa tambahan bahan aditif seperti bahan pengisi, akselerator, bahan pemvulkanisasi, aktivator, dan pelunak. Dalam penelitian ini digunakan carbon black (CB) sebagai bahan pengisi yang berfungsi untuk mengimprovisasi sifat vulkanisat.

Dalam studi ini dipelajari kinetika dekomposisi termal EPDM menggunakan thermogravimetric analysis (TGA). TGA adalah teknik yang paling umum, simpel, dan cepat untuk analisis kinetika untuk proses devolatilisasi. Analisis kinetika telah menjadi topik yang menarik bagi banyak peneliti yang terlibat dalam bidang dekomposisi termal. Studi kinetika solid-state semakin penting dalam analisis termal dan membantu perhitungan parameter menggunakan persamaan Arrhenius dan untuk menentukan mekanisme reaksi dekomposisi. Pemanasan dengan kecepatan rendah lebih disarankan, namun juga tergantung pada jenis bahan dan kecepatan reaksinya (Nowicki \& Markowski, 2012). Studi tentang stabilitas termal polimer sangat penting dalam desain produk polimer untuk mengetahui rentang suhu bahan tersebut agar dapat dipakai tanpa mengalami degradasi (Sholeh et al., 2015).

Beberapa studi terdahulu telah menggunakan analisis TGA untuk berbagai material seperti plastik (Aigbodion \& Hassan, 2012; Zhou et al., 2006), serat alam (Yao et al., 2008), biomassa (Slopiecka et al., 2011; Ahiduzzaman \& Islam, 2015; Poletto et al., 2012), limbah elektronik (Quan et al., 2013), logam transisi (Chaudary et al., 2016), biodiesel (Dwivedi \& Sharma, 2016), karet dan campuran karet (Komalan et al., 2008; Li et al., 2010; Alneamah \& Almaamori, 2015; Paul \& Joseph, 2014; Vijayalekshmi \& Majeed, 2013; Iqbal et al., 2015; Brostow et al., 2011), dan resin (Kandare et al., 2008; Tibiletti et al., 2011; Sholeh et al., 2015).
Penelitian sebelumnya dengan menggunakan metode TGA mendapatkan hasil bahwa vulkanisat EPDM dengan 60 phr CB dengan berbagai variasi kandungan etilen terdekomposisi dalam dua tahap menggunakan gas nitrogen dan terdekomposisi maksimal pada $452-462^{\circ} \mathrm{C}$ (Gamlin et al., 2000). Aziz et al. (2005) mendapatkan hasil bahwa EPDM yang divulkanisasi dengan $50 \mathrm{phr} \mathrm{CB}$ dengan berbagai macam antioksidan terdegradasi seluruhnya pada suhu $498-509^{\circ} \mathrm{C}$ dalam dua tahap menggunakan udara (Aziz \& Basfar, 2005). Komalan et al. (2008) mendapatkan hasil bahwa karet EPDM terdekomposisi menggunakan gas nitrogen pada suhu $401^{\circ} \mathrm{C}$ dan terdekomposisi sempurna pada suhu $500^{\circ} \mathrm{C}$. Vulkanisat O-ring dari EPDM mulai terdegradasi dengan menggunakan gas nitrogen pada suhu $118^{\circ} \mathrm{C}$ dan puncak degradasi terjadi pada suhu $476^{\circ} \mathrm{C}$ (Sugama et al., 2015). Analisis termal EPDM dengan variasi jumlah bahan pengisi perlu dipelajari. Oleh karena itu dalam penelitian ini dilakukan studi termogravimetri vulkanisat EPDM dengan berbagai variasi sistem vulkanisasi dan jumlah bahan pengisi carbon black dengan menggunakan gas oksigen dan mendapatkan parameter kinetika reaksi berdasarkan persamaan Coats Redfern.

\section{BAHAN DAN METODE \\ Bahan Penelitian}

Vulkanisat EPDM dibuat dengan formulasi yang telah diuraikan pada publikasi sebelumnya (Mayasari \& Yuniari, 2016) dengan bahan-bahan EPDM Keltan 4551 A (dengan kandungan ENB 8,7\%), CB N220 (Ex.Korea), ZnO (Ex. Indoxide), asam stearat Aflux $42 \mathrm{M}$, TMQ (Ex. Kemai), paraffin wax Antilux 654 A, paraffinic oil, TMTD, MBT, sulfur (Ex. Miwon) dengan sistem vulkanisasi efisien, semi-efisien, dan konvensional. Formulasi yang digunakan ditampilkan pada Tabel 1 .

\section{Peralatan Penelitian}

Penelitian ini menggunakan two roll mills skala laboratorium untuk komponding, mesin kempa hidrolik untuk vulkanisasi, reometer Gotech 3000A untuk mengetahui reologi kompon, dan Shimadzu DTG 60 untuk analisis termogravimetri.

\section{Metode Penelitian}

Pembuatan vulkanisat EPDM dilakukan dengan metode dan waktu pencampuran sesuai de- 
Tabel 1. Formulasi vulkanisat EPDM.

\begin{tabular}{lrrrrrrrrr}
\hline \multirow{2}{*}{ Bahan } & \multicolumn{3}{c}{ EV (Efisien) } & \multicolumn{3}{c}{ SEV (Semi-efisien) } & \multicolumn{2}{c}{ CV (Konvensional) } \\
\cline { 2 - 9 } & EV1 & EV2 & EV3 & SEV1 & SEV2 & SEV3 & CV1 & CV2 & CV3 \\
\cline { 2 - 9 } & phr & phr & phr & phr & phr & phr & phr & phr & phr \\
\hline EPDM & 100 & 100 & 100 & 100 & 100 & 100 & 100 & 100 & 100 \\
Carbon black (N220) & 50 & 60 & 70 & 50 & 60 & 70 & 50 & 60 & 70 \\
ZnO & 5 & 5 & 5 & 5 & 5 & 5 & 5 & 5 & 5 \\
Asam stearat & 1 & 1 & 1 & 1 & 1 & 1 & 1 & 1 & 1 \\
TMQ & 1 & 1 & 1 & 1 & 1 & 1 & 1 & 1 & 1 \\
Paraffin wax & 0,5 & 0,5 & 0,5 & 0,5 & 0,5 & 0,5 & 0,5 & 0,5 & 0,5 \\
Paraffinic oil & 5 & 5 & 5 & 5 & 5 & 5 & 5 & 5 & 5 \\
TMTD & 1 & 1 & 1 & 1,4 & 1,4 & 1,4 & 0,75 & 0,75 & 0,75 \\
MBT & 1 & 1 & 1 & 1 & 1 & 1 & 0,5 & 0,5 & 0,5 \\
Sulfur & 0,8 & 0,8 & 0,8 & 1,7 & 1,7 & 1,7 & 2,5 & 2,5 & 2,5 \\
\hline
\end{tabular}

ngan yang telah diuraikan pada publikasi sebelumnya (Mayasari \& Yuniari, 2016). Pembuatan vulkanisat EPDM menggunakan two roll mills skala laboratorium, selanjutnya kompon divulkanisasi pada $170^{\circ} \mathrm{C}$ dengan tekanan $150 \mathrm{~kg} / \mathrm{cm}^{2}$ dengan waktu berdasarkan reometer.

Analisis termogravimetri diamati dengan menggunakan Shimadzu DTG 60. Gas oksigen dialirkan dengan kecepatan $30 \mathrm{ml} / \mathrm{min}$ pada kisaran suhu $30-800^{\circ} \mathrm{C}$ menggunakan wadah alumina dengan sampel bubuk EPDM sebanyak 5-8 mg dengan kecepatan pemanasan $5^{\circ} \mathrm{C} /$ menit. Dari data yang diperoleh, massa yang hilang dapat dihitung dengan persamaan sebagai berikut:

$\%$ massa terdekomposisi $=\frac{\left(W_{0}-W_{\mathrm{t}}\right)}{W_{0}} \times 100 \%$

$W_{\text {o }}$ adalah massa awal, $W_{\mathrm{t}}$ adalah massa saat tertentu pada pemanasan.

\section{HASIL DAN PEMBAHASAN}

TGA adalah salah satu metode analisis termal suatu sampel dengan memperhatikan penurunan massa selama sampel diberikan perlakuan panas yang dilakukan dalam lingkungan atmosfer. Grafik TG (termogravimetri) ditampilkan sebagai fungsi penurunan massa terhadap kenaikan temperatur. Grafik TG untuk masing-masing sistem vulkanisasi dengan berbagai variasi kandungan CB disajikan pada Gambar 2.

Grafik DTG (derivatif termogravimetri) adalah penurunan grafik TG untuk menghasilkan $\mathrm{dm} /$ $d t$ atau laju penurunan massa terhadap temperatur atau bisa juga terhadap waktu. Luasan bidang yang dibatasi garis DTG menunjukkan besarnya penu-
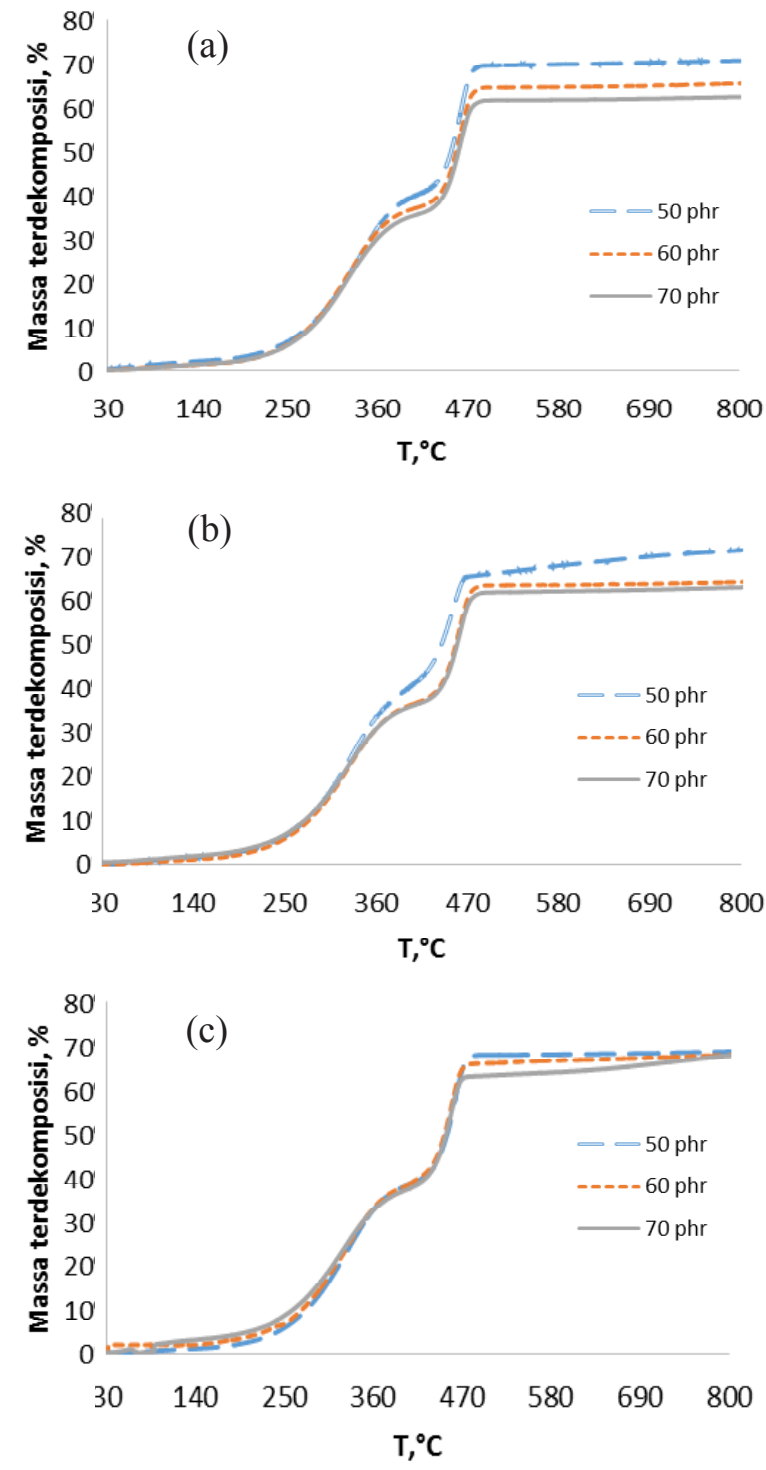

Gambar 2. Kurva termogravimetri: (a) EV, (b) $\mathrm{SEV}$, dan (c) CV. 
runan massa yang terjadi, sedangkan temperatur saat terjadi dekomposisi massa tertinggi ditunjukkan dengan peak terendah. Grafik DTG vulkanisat EPDM disajikan pada Gambar 3.

Dari grafik TGA dapat dilihat bahwa EPDM memiliki volatile matter initiation temperature (ITVM) pada suhu $205-212^{\circ} \mathrm{C}$. ITVM adalah temperatur dimana massa mulai terdekomposisi. EPDM memiliki burning temperature (BT) pada suhu $480-492^{\circ} \mathrm{C}$ dengan massa yang hilang sebanyak $61,64-69,75 \%$. BT adalah temperatur dimana massa konstan pada akhir tahap pembakaran, pada temperatur ini telah terjadi dekomposisi sempurna, tidak lagi ada penurunan massa yang terjadi. Dari grafik DTG terlihat bahwa dekomposisi EPDM
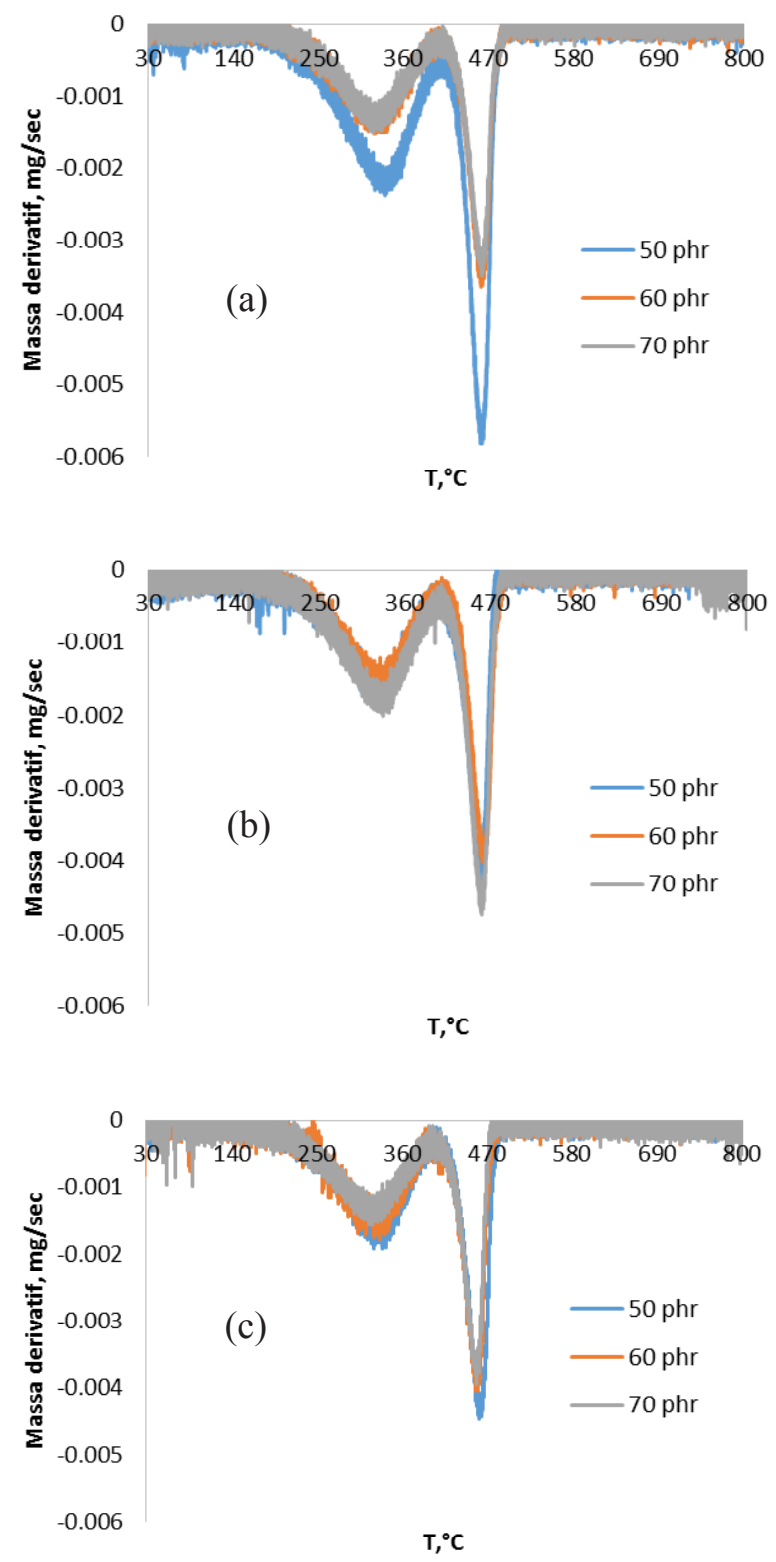

Gambar 3. Kurva DTG (a) EV (b) SEV (c) CV. terjadi dalam dua tahap.

Tahap awal dekomposisi vulkanisat EPDM adalah terjadinya oksidasi EPDM serta terlepasnya bahan mudah menguap. Tahap kedua adalah proses dekomposisi EPDM. Tahap pertama terjadi pada suhu $205-212^{\circ} \mathrm{C}$ sampai dengan suhu sekitar $400-417^{\circ} \mathrm{C}$. Pada tahap ini terjadi oksidasi EPDM, karena dalam penelitian ini digunakan EPDM dengan kandungan ENB (ethylidine-2-norbornene) sebesar 8,7\%, dimana semakin besar kandungan ENB maka semakin mudah EPDM teroksidasi. Pembentukan radikal bebas hasil reaksi oksidasi akan menyerang ikatan rangkap pada ENB di dalam rantai EPDM (Ning et al. 2014). Pada tahap awal ini juga terjadi pelepasan zat yang mudah menguap seperti minyak proses, asam stearat, TMQ, TMTD, MBT (titik didih masing-masing $302^{\circ} \mathrm{C}, 361^{\circ} \mathrm{C}, 320^{\circ} \mathrm{C}, 307^{\circ} \mathrm{C}, 305^{\circ} \mathrm{C}$ ). Kemudian dilanjutkan dengan tahap ke-2 antara suhu 400$417^{\circ} \mathrm{C}$ hingga $480-492^{\circ} \mathrm{C}$. Pada tahap ini EPDM mulai terdekomposisi, yaitu terjadinya pemecahan ikatan kimia secara termal. Selanjutnya, akan tersisa arang karbon. Dari penelitian yang dilakukan, didapatkan massa akhir sekitar 30,25-38,36\%. Residu yang cukup besar dalam proses pembakaran menunjukkan bahwa vulkanisat EPDM yang dibuat memiliki ketahanan yang cukup baik terhadap dekomposisi termal. Tahapan yang terjadi pada vulkanisat EPDM dengan berbagai variasi CB dan sistem vulkanisasi dapat dilihat pada Tabel 2 .

Dari Tabel 2 diketahui bahwa massa terdekomposisi semakin menurun dengan peningkatan kandungan CB. Hal ini terjadi karena semakin banyak kandungan karbon dalam vulkanisat, maka residu pembakaran semakin meningkat, karena yang tersisa adalah arang karbon. Arang karbon bereaksi dengan oksigen akan membentuk gas karbon monoksida serta karbon dioksida (Gambar 4).

Suhu saat vulkanisat mulai terdekomposisi tidak jauh berbeda baik pada berbagai variasi jumlah penambahan $\mathrm{CB}$ maupun variasi sistem vulkanisasi. Hal ini dapat terjadi karena jenis bahan yang digunakan sama, sehingga ketahanan termal-

$$
\begin{gathered}
\mathrm{C}+1 / 2 \mathrm{O}_{2} \rightarrow \mathrm{CO} \\
\mathrm{CO}+1 / 2 \mathrm{O}_{2} \rightarrow \mathrm{CO}_{2} \\
\mathrm{C}+\mathrm{CO}_{2} \rightarrow 2 \mathrm{CO}
\end{gathered}
$$

Gambar 4. Reaksi antara karbon dan oksigen. 
Tabel 2. Tahapan dekomposisi termal EPDM.

\begin{tabular}{ccccc}
\hline Sampel & Tahap & $\begin{array}{c}\text { Rentang Suhu, } \\
{ }^{\circ} \mathrm{C}\end{array}$ & $\begin{array}{c}\text { Temperatur } \\
\text { puncak, }{ }^{\circ} \mathrm{C}\end{array}$ & Massa terdekomposisi, \% \\
\hline EV1 & I & $210-417$ & 335 & 41,07 \\
$(50 \mathrm{phr}$ CB $)$ & II & $417-490$ & 459 & 69,75 \\
\hline EV2 & I & $210-417$ & 322 & 37,94 \\
$(60$ phr CB $)$ & II & $417-490$ & 460 & 64,72 \\
\hline EV3 & I & $210-410$ & 321 & 35,88 \\
$(70$ phr CB $)$ & II & $410-486$ & 461 & 61,64 \\
\hline SEV1 & I & $205-412$ & 329 & 43,41 \\
$(50$ phr CB $)$ & II & $412-480$ & 456 & 71,50 \\
\hline SEV2 & I & $205-415$ & 331 & 37,28 \\
$(60$ phr CB $)$ & II & $415-495$ & 461 & 64,23 \\
\hline SEV3 & I & $207-406$ & 332 & 38,05 \\
$(70$ phr CB $)$ & II & $406-492$ & 458 & 38,57 \\
\hline CV1 & I & $212-408$ & 334 & 67,86 \\
$(50$ phr CB $)$ & II & $408-490$ & 461 & 38,16 \\
\hline CV2 & I & $207-400$ & 332 & 65,80 \\
$(60$ phr CB $)$ & II & $400-482$ & 455 & 38,03 \\
\hline CV3 & I & $205-409$ & 317 & 62,92 \\
\hline$(70$ phr CB $)$ & II & $409-482$ & 457 & \\
\hline
\end{tabular}

nya tidak jauh berbeda.

Data TG dapat digunakan untuk mencari energi aktivasi dan pre-eksponensial faktor untuk mendapatkan desain optimal untuk membuat suatu produk. Parameter kinetik dapat ditentukan oleh kecepatan reaksinya. Analisis kinetik dari proses dekomposisi melibatkan model reaksi dan persamaan Arrhenius. Dalam studi ini digunakan persamaan Coats Redfern seperti beberapa studi sebelumnya (Quan et al., 2013; Komalan et al., 2008; Sholeh et al., 2015; Kahrizsangi \& Abbasi, 2008). Persamaan kinetika dapat ditulis sebagai berikut:

$\frac{d x}{d t}=k f(x)$

$x$ adalah konversi dan $k$ adalah konstanta kecepatan reaksi yang dihitung dengan persamaan (3) dan (4) berikut:

$x=\frac{W_{0}-W_{\mathrm{t}}}{W_{0}-W_{f}}$
$k=A \exp \left(-\frac{E}{R T}\right)$

$f(x)=1-x$

$W_{f}$ adalah massa akhir sampel, $A$ adalah pre-exponential factor, $E$ adalah energi aktivasi, $R$ adalah konstanta gas, dan $T$ adalah suhu.
Untuk laju pemanasan $(\beta)$ konstan,

$\beta=\frac{d T}{d t}$

Maka persamaan (2) dapat ditulis:

$\frac{d x}{d T}=\frac{A}{\beta}(1-x) \exp \left(-\frac{E}{R T}\right)$

Dari hasil integral, persamaan (7) dapat ditulis:

$\ln \left[-\frac{\ln (1-x)}{T^{2}}\right]=\ln \left[\frac{A R}{\beta E}\left(1-\frac{2 R T}{E}\right)\right]-\frac{E}{R T}$

2RT/E dapat diabaikan karena hampir sama dengan 1, maka Persamaan (8) dapat ditulis:

Untuk order reaksi $(n)=1$

$\ln \left[-\frac{\ln (1-x)}{T^{2}}\right]=\ln \left(\frac{A R}{\beta E}\right)-\frac{E}{R T}$

Untuk $n \neq 1$

$\ln \left[1-\frac{(1-x)^{1-n}}{T^{2}(1-n)}\right]=\ln \left[\frac{A R}{\beta E}\left(1-\frac{2 R T}{E}\right)\right]-\frac{E}{R T}$

Pada Persamaan (9), nilai $\ln \left[-\frac{\ln (1-x)}{T^{2}}\right]$ linier dengan $1 / T$ dengan slope sebagai $-E / R$, sedangkan intersep dapat digunakan untuk menghitung $A$. Dalam penelitian ini, diasumsikan terjadi reaksi orde satu karena tingkat pemanasan yang lambat dan ukuran sampel yang relatif kecil, sehingga transfer panas dan transfer massa dapat diabaikan. Plot $\ln \left[-\frac{\ln (1-x)}{T^{2}}\right]$ dengan $1 / T$ disajikan pada Gam- 
bar 5 .

Hasil regresi linier pada Gambar 5 menunjukkan bahwa dekomposisi tahap pertama dan kedua dapat digambarkan dengan Persamaan (3). Nilai E dan A terangkum pada Tabel 3.

Dari Tabel 3 diketahui bahwa energi aktivasi bernilai positif, yang berarti dari hasil perhitungan, didapat hasil yang positif untuk semua parameter, hal ini menunjukkan bahwa tidak terjadi fase transisi pada temperatur yang dipilih. Dari grafik didapatkan koefisien korelasi pada setiap tahap selu- ruhnya mendekati 1 , hal ini membuktikan bahwa energi aktivasi setiap tahap tepat didekati dengan reaksi orde 1.

Energi aktivasi menunjukkan besarnya energi yang dibutuhkan untuk memulai dekomposisi. Dari Tabel 3 dapat diketahui bahwa energi aktivasi pada tahap I lebih kecil daripada tahap II. Hal ini dikarenakan pada tahap 1, energi yang dibutuhkan hanya untuk menghilangkan/membakar bahan mudah menguap. Menurut Chaudary et al. (2016), rendahnya energi aktivasi menunjukkan

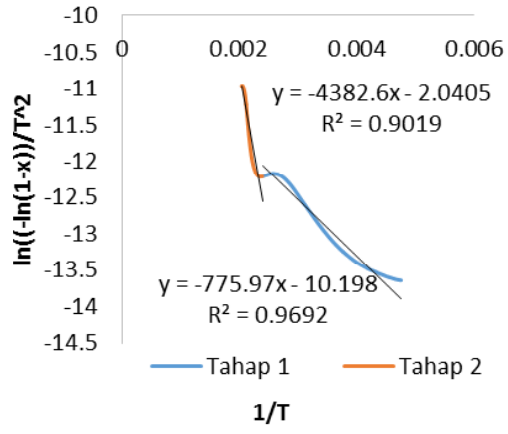

(a)

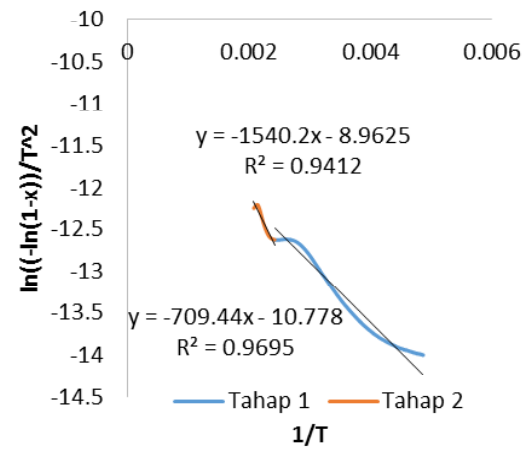

(d)

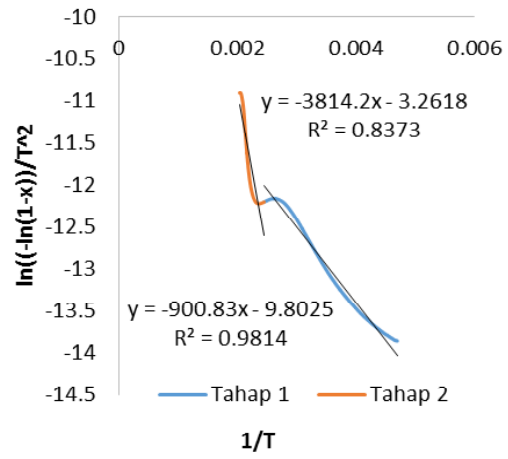

$(\mathrm{g})$

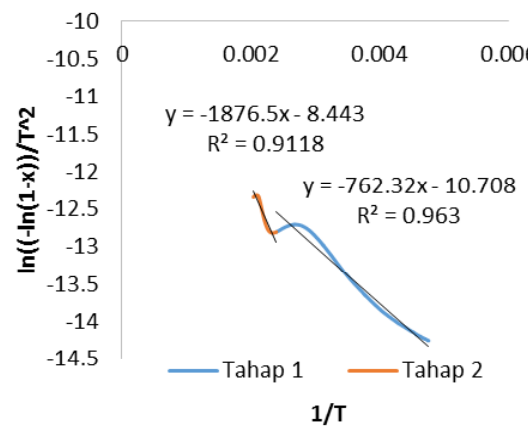

(b)

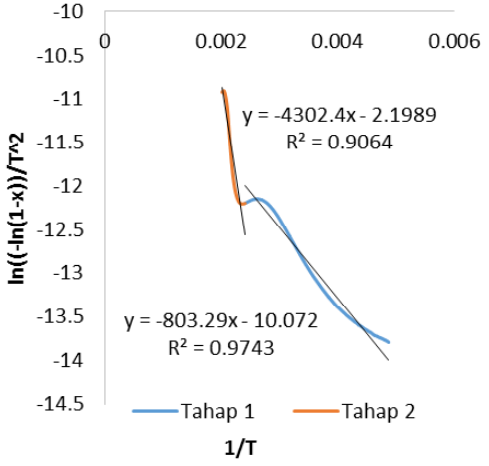

(e)

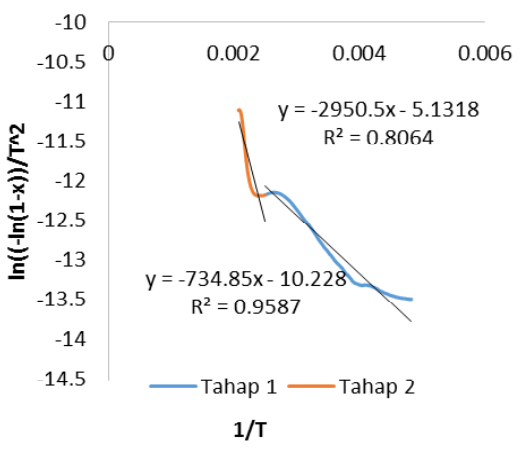

(h)

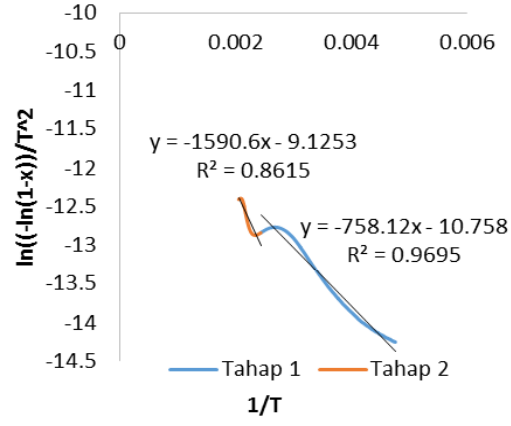

(c)

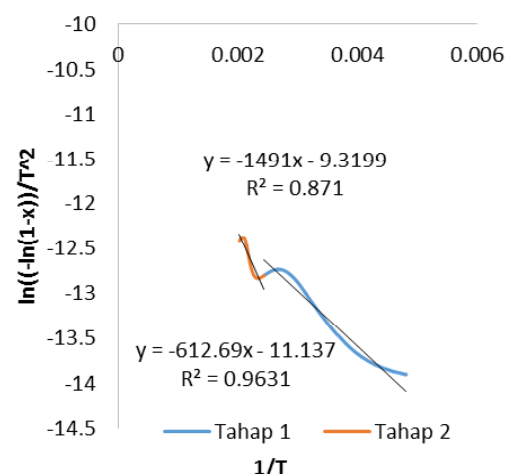

(f)

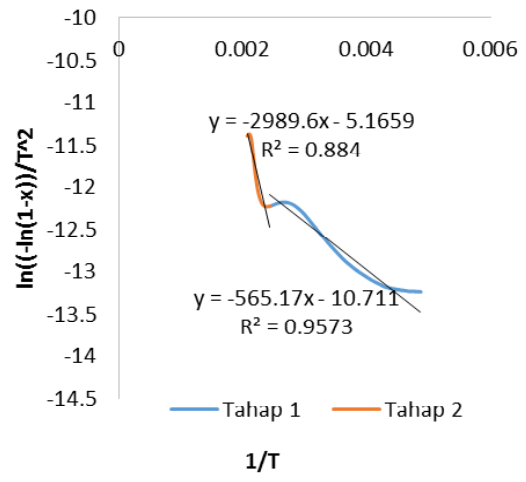

(i)

Gambar 5. Regresi linier persamaan Coats Redfern (a) EV 50 phr (b) EV 60 phr (c) EV 70 phr (d) SEV $50 \mathrm{phr}$ (e) SEV $60 \mathrm{phr}$ (f) CV $70 \mathrm{phr}$ (g) CV $50 \mathrm{phr}$ (h) CV $60 \mathrm{phr}$ (i) CV $70 \mathrm{phr}$. 
Tabel 3. Parameter kinetika dekomposisi EPDM.

\begin{tabular}{ccccc}
\hline Sampel & Tahap & Rentang suhu $\left({ }^{\circ} \mathrm{C}\right)$ & $\mathrm{E}(\mathrm{kJ} / \mathrm{mol})$ & $\mathrm{A}\left(\mathrm{menit}^{-1}\right)$ \\
\hline EV1 & I & $210-417$ & 6.45 & $3.72 \times 10^{-5}$ \\
$(50 \mathrm{phr} \mathrm{CB})$ & II & $417-490$ & 36.44 & $1.29 \times 10^{-1}$ \\
\hline EV2 & I & $210-417$ & 6.34 & $2.24 \times 10^{-5}$ \\
$(60 \mathrm{phr} \mathrm{CB})$ & II & $417-490$ & 15.60 & $2.15 \times 10^{-4}$ \\
\hline EV3 & I & $210-410$ & 6.30 & $2.13 \times 10^{-5}$ \\
$(70 \mathrm{phr} \mathrm{CB})$ & II & $410-486$ & 13.22 & $1.09 \times 10^{-4}$ \\
\hline SEV1 & I & $205-412$ & 5.90 & $2.08 \times 10^{-5}$ \\
$(50 \mathrm{phr} \mathrm{CB})$ & II & $412-480$ & 12.81 & $1.28 \times 10^{-4}$ \\
\hline SEV2 & I & $205-415$ & 6.68 & $4.22 \times 10^{-5}$ \\
$(60 \mathrm{phr} \mathrm{CB})$ & II & $415-495$ & 35.77 & $1.11 \times 10^{-1}$ \\
\hline SEV3 & I & $207-406$ & 5.09 & $1.46 \times 10^{-5}$ \\
$(70 \mathrm{phr} \mathrm{CB})$ & II & $406-492$ & 12.40 & $8.96 \times 10^{-5}$ \\
\hline $\mathrm{CV} 1$ & I & $213-408$ & 7.56 & $5.53 \times 10^{-5}$ \\
$(50 \mathrm{phr} \mathrm{CB})$ & II & $408-490$ & 31.94 & $3.83 \times 10^{-2}$ \\
\hline $\mathrm{CV} 2$ & I & $207-400$ & 6.11 & $3.61 \times 10^{-5}$ \\
$(60 \mathrm{phr} \mathrm{CB})$ & II & $400-482$ & 24.53 & $5.91 \times 10^{-3}$ \\
\hline $\mathrm{CV} 3$ & I & $205-409$ & 4.70 & $2.23 \times 10^{-5}$ \\
$(70 \mathrm{phr} \mathrm{CB})$ & II & $409-482$ & 24.86 & $5.71 \times 10^{-3}$ \\
\hline
\end{tabular}

lemahnya ikatan antara bahan mudah menguap dengan polimer (Chaudary et al., 2016). Pada tahap 2 dibutuhkan energi yang lebih besar untuk memecah karet agar terdekomposisi. Lebih besarnya energi aktivasi pada tahap kedua menggambarkan bahwa dekomposisi berjalan lambat. Hal ini juga didukung oleh pre-eksponensial faktor yang nilainya lebih besar pada tahap kedua.

Energi aktivasi dapat berubah tergantung dari komposisi vulkanisat dan sistem vulkanisasinya. Dari hasil penelitian didapat energi aktivasi semakin berkurang dengan meningkatknya kandungan $\mathrm{CB}$, kecuali pada formulasi SEV $60 \mathrm{phr}$. Energi aktivasi merupakan energi yang dibutuhkan untuk memecah ikatan-ikatan yang terjadi dan kemudian memulai reaksi. CB merupakan reinforcing filler, bahan pengisi yang memperbaiki sifat mekanis vulkanisat. CB dapat menjadi penguat yang baik jika partikel $\mathrm{CB}$ terdispersi merata dalam matriks karet, namun pada jumlah tertentu juga dapat menurunkan beberapa sifat mekaniknya (Sangwichien et al., 2008; Dijkhuis et al., 2009; Povacz et al., 2014). Maka dalam studi ini dimungkinkan terjadi overloading filler, dimana pemberian bahan pengisi (filler) yang terlalu banyak membuat partikel CB tidak terdispersi dengan baik dalam molekul karet, sehingga dimungkinkan ikatan yang terjadi lebih banyak terdapat pada EPDM dengan 50 phr CB daripada EPDM dengan
60 dan 70 phr CB. Berkurangnya energi aktivasi ini juga didukung oleh penelitian Jovanovic et al. (2009) yang mendapatkan hasil bahwa energi aktivasi crosslinking NBR naik dengan penambahan CB sampai $40 \mathrm{phr}$, namun kemudian turun drastis untuk penambahan CB diatas $40 \mathrm{phr}$ (Jovanović et al., 2009)

Dalam penelitian ini, variasi sistem vulkanisasi tidak nampak pengaruhnya terhadap besarnya energi aktivasi. Besarnya energi aktivasi selain dipengaruhi oleh kandungan bahan pengisi juga dapat dipengaruhi oleh metode estimasi parameter kinetika, massa dan ukuran spesimen, laju alir dan kondisi operasi. Sedangkan temperatur leleh, morfologi, serta jumlah bahan penguat mempengaruhi kestabilan termal (Komalan et al., 2008).

\section{KESIMPULAN}

Proses dekomposisi termal vulkanisat EPDM terjadi dalam dua tahap. Tahap awal pada suhu $205-212^{\circ} \mathrm{C}$ sampai suhu $400-417^{\circ} \mathrm{C}$ yaitu oksidasi EPDM dan lepasnya bahan mudah menguap kemudian tahap kedua adalah terdekomposisinya EPDM pada suhu sekitar $400-417^{\circ} \mathrm{C}$ sampai suhu $480-492^{\circ} \mathrm{C}$. Temperatur puncak saat terjadinya dekomposisi termal adalah pada suhu sekitar 317$335^{\circ} \mathrm{C}$ pada tahap I dan $455-461^{\circ} \mathrm{C}$ pada tahap II. Kandungan CB dalam vulkanisat memberikan pengaruh yang cukup besar terhadap energi akti- 
vasi. Secara umum, semakin banyak kandungan $\mathrm{CB}$, energi aktivasi semakin menurun. Dari persamaan Coats Redfern, didapat parameter kinetika energi aktivasi untuk tahap I sebesar 4,70-7,56 kJ/ mol dan untuk tahap II sebesar 13,22-36,44 kJ/ mol. Massa yang terdekomposisi meningkat dengan penurunan kandungan $\mathrm{CB}$, yaitu antara 61,64$69,75 \%$. Variasi sistem vulkanisasi tidak memberi pengaruh signifikan terhadap energi aktivasi dan massa terdekomposisi. Informasi stabilitas termal ini dapat digunakan sebagai dasar untuk membuat desain dan formulasi produk yang diinginkan.

\section{UCAPAN TERIMAKASIH}

Penelitian ini didanai oleh DIPA Balai Besar Kulit, Karet dan Plastik tahun anggaran 2015. Penulis mengucapkan terimakasih pada seluruh anggota tim peneliti dan Bapak Muhammad Sholeh untuk saran yang telah diberikan.

\section{DAFTAR PUSTAKA}

Ahiduzzaman, M., \& Islam, A. K. M. S. (2015). Thermogravimetric and kinetic analysis of different varieties of rice husk. Procedia Engineering, 105, 646-651, http://dx.doi.org/10.1016/j.proeng.2015.05.043

Aigbodion, V. S., \& Hassan, S. B. (2012). Kinetics of isothermal degradation studies by thermogravimetric data : effect of orange peels ash on thermal properties of high density polyethylene. Journal Material Environment Science, 3(6): $1027-36$

Alneamah, M., \& Almaamori, M. (2015). Study of thermal stability of nitrile rubber/polyimide compounds. International Journal of Materials and Chemistry, 5(1), 1-3.

Aziz,A., \& Basfar. (2005). Thermal stability of radiation vulcanized EPDM rubber. Arab International Conference on Polymer Science \& Technology, 18-19.

Brostow, W., Datashvili, T., \& Geodakyan, J., \& Lou, J. (2011). Thermal and mechanical properties of EPDM/PP + thermal shock-resistant ceramic composites. Journal of Material Science, 46, 2445-55.

http://dx.doi.org/10.1007/s10853-010-5091-2

Chaudary, R. G., Ali, P., Gandhare, N. V., Tanna, J. A., \& Juneja, H. D. (2016). Thermal decomposition kinetics of some transition metal coordination polymers of fumaroyl bis (paramethoxyphenylcarbamide) using DTG / DTA techniques. Arabian Journal of Chemistry. http://dx.doi.org/10.1016/j.arabjc.2016.03.008

Choi, S., Kim, J., \& Woo, C. (2006). Accelerated thermal aging behaviors of EPDM and NBR vulcanizates. Bulletin of Korean Chemical Society. 2(6), 936-38.

Dijkhuis, K. A. J., Noordermeer, J. W. M., \& Dierkes, W. K. (2009). The relationship between crosslink system, network structure and material properties of carbon black reinforced EPDM. European Polymer Journal, 45(11), 3302-12.

http://dx.doi.org/10.1016/j.eurpolymj.2009.06.029

Dwivedi, G., \& Sharma, M. P. (2016). Experimental investigation on thermal stability of pongamia biodiesel by thermogravimetric analysis. Egyptian Journal of Petroleum, 25(1).

http://dx.doi.org/10.1016/j.ejpe.2015.06.008

Gamlin, C., Markovic, M. G., Dutta, N. K., \& Choudhury, N. R. (2000). Structural effects on the decomposition kinetics of EPDM elastomers by high-resolution TGA and modulated TGA. Journal of Thermal Analysis and Calorimetry, 59, 319-36. http://dx.doi.org/10.1023/A:1010164702571

Iqbal, J., Pandey, K. N., Verma, V., Singh, P., \& Mishra, R. M. (2015). Physico-mechanical and thermal behaviour of binary blends of EPDM and LLDPE. European Journal of Advances in Engineering and Technology, 2(10), 43-48.

Jovanović, V., Simendić, J. B., Jovanović, S. S., Marković, G., \& Cincović, M. M. (2009). The influence of carbon black on curing kinetics and thermal aging of acrylonitrile-butadiene rubber. Chemical Industry and Chemical Engineering Quarterly, 15(4), 283-89. http://dx.doi.org/10.2298/CICEQ0904283J

Kahrizsangi, R. E., \& Abbasi, M. H. (2008). Evaluation of reliability of coats-redfern method for kinetic analysis of non-isothermal TGA. Transactions of Nonferrous Metals Society of China, 18, 2-6.

Kandare, E., Kandola, B. K, Price, D., Nazare, S., \& Horrocks, R. A. (2008). Study of the thermal decomposition of flame-retarded unsaturated polyester resins by thermogravimetric analysis and Py-GC / MS. Polymer Degradation and Stability, 93, 1996-2006.

http://dx.doi.org/10.1016/j.polymdegradstab.2008.03.032

Komalan, C., Elias, K., Thomas, K., Susan, V., \& Thomas, S. (2008). Thermogravimetric and wide angle X-Ray diffraction analysis of thermoplastic elastomers from nylon copolymer and EPDM rubber. Polymer Degradation and Stability, 93(12), 2104-12.

http://dx.doi.org/10.1016/j.polymdegradstab.2008.08.011

Li, C., Zhong, J., Yang, L., Li, S., \& Kong, L. (2010). Studies on the properties and the thermal decomposition kinetics of natural rubber prepared with calcium chloride. E-Polymers, 72, 1-9.

Mayasari, H. E., \& Yuniari, A. (2016). Effect of vulcanization system and carbon black on mechanical and swelling properties of EPDM blends. Majalah Kulit, Karet, dan Plastik, 32(1), 
59-64.

http://dx.doi.org/10.20543/mkkp.v32i1.706

Ning, N., Ma, Q., Zhang, Y., Zhang, L., \& Wu, H. (2014). Enhanced thermo-oxidative aging resistance of EPDM at high temperature by using synergistic antioxidants. Polymer Degradation and Stability, 102, 1-8. http://dx.doi.org/10.1016/j. polymdegradstab.2014.01.037

Nowicki, L., \& Markowski, M. (2012). Kinetic analysis of thermogravimetric data collected from bigger samples. Chemical and Process Engineering, 33(1), 85-94. http://dx.doi.org/10.2478/v10176-012-0008-z

Paul, P., \& Joseph, R. (2014). EPDM/CIIR blends: rheology, air permeability, thermal stability and thermal diffusivity. International Journal of Science, 3(4), 1359-70.

Poletto, M., Zattera A. J., \& Santana, R. M. C. (2012). Bioresource technology thermal decomposition of wood: kinetics and degradation mechanisms. Bioresource Technology, 126, 7-12. http://dx.doi.org/10.1016/j.biortech.2012.08.133

Povacz, M., Wallner, G. M., \& Lang, R. W. (2014). Black-pigmented polypropylene materials for solar thermal absorbers - effect of carbon black concentration on morphology and performance properties. Solar Energy, 110, 420-26. http://dx.doi.org/10.1016/j.solener.2014.09.024

Quan, C., Li, A., \& Gao, N. (2013). Combustion and pyrolysis of electronic waste : thermogravimetric analysisandkineticmodel.ProcediaEnvironmental Sciences, 18, 776-82. http://dx.doi.org/10.1016/j.proenv.2013.04.104

Sangwichien, C., Sumanatrakool, P., \& Patarapaiboolchai, O. (2008). Effect of filler loading on curing characteristics and mechanical properties of thermoplastic vulcanizate. Chiang Mai Journal Science, 35(1), 141-49.

Sholeh, M., Sugihartono, \& Supraptiningsih. (2015). Thermogravimetric study of decomposition kinetics of unsaturated polyester with kaolin and sawdust as filler. Prosiding Seminar Nasional Kulit, Karet, dan Plastik, 115-24.
Slopiecka, K., Bartocci, P., \& Fantozzi, F. (2011). Thermogravimetric analysis and kinetic study of poplar wood pyrolysis. International Conference on Applied Energy, 1687-98.

Sugama, T., Pyatina, T., Redline, E., Mcelhanon, J., \& Blankenship, D. (2015). Degradation of different elastomeric polymers in simulated geothermal environments at 300 C. Polymer Degradation and Stability, 120, 328-39.

http://dx.doi.org/10.1016/j.polymdegradstab.2015.07.010

Tibiletti, L., Longuet, C., Ferry, L., Coutelen, P., Mas, A., Robin, J., \& Lopez-cuesta, J. (2011). Thermal degradation and fire behaviour of unsaturated polyesters filled with metallic oxides. Polymer Degradation and Stability, 96, 67-75.

http://dx.doi.org/10.1016/j.polymdegradstab.2010.10.015

Vijayalekshmi, V., \& Majeed, S. S. M. (2013). Mechanical, thermal and electrical properties of EPDM / Silicone blend nanocomposites. International Journal of Engineering Research and Applications, 3(2), 1177-80.

Yao, F., Wu, Q., Lei, Y., Guo, W., \& Xu, Y. (2008). Thermal decomposition kinetics of natural fibers: activation energy with dynamic thermogravimetric analysis. Polymer Degradation and Stability, 93, 90-98.

http://dx.doi.org/10.1016/j.polymdegradstab.2007.10.012

Zhou, L., Wang, Y., Huang, Q., \& Cai, J. (2006). Thermogravimetric characteristics and kinetic of plastic and biomass blends co-pyrolysis. Fuel Processing Technology, 87, 963-69. http://dx.doi.org/10.1016/j.fuproc.2006.07.002 
